\title{
Improvement of Fisheries Management by Marine and Fisheries of Semarang City
}

\author{
Astrid Priscillia $^{1 *}$, Amiek Soemarmi $^{1}$, Amalia Diamantina $^{1}$ \\ \{astrid.priscillia@gmail.com¹ ${ }^{1}$, amiek_soemarmi@live.undip.ac.id ${ }^{2}$, \\ amalia_diamantina@live.undip.ac.id\} \\ Fakultas Hukum, Universitas Diponegoro, Semarang, Jawa Tengah, Indonesia ${ }^{1,2,3}$
}

\begin{abstract}
Law No. 45 of 2009 concerning Fisheries grants authority to the government and regional government in accordance with their authority has been the basis to conduct marine management for the greatest prosperity of the people through the utilization and validation of marine resources using the blue economy principle. The research focuses on the efforts of the Marine Service and Semarang City Fisheries to improve the management of aquaculture, and to overcome the obstacles experienced by the Semarang City Maritime and Fisheries Office. In this study, the authors use the normative juridical approach method, an approach that is based on existing legal rules and facts. Using a normative approach, the paper refers to primary legal materials, secondary legal materials, and tertiary legal materials. The results showed that the Semarang City Maritime and Fisheries Service Office attempted to improve the management of aquaculture in an Optimal Enhancement of Aquaculture Fisheries Resources, while maintaining environmental sustainability through improving the quality of human resources, optimally managing the potential of aquaculture fisheries through the programs implemented in Maritime and Fisheries Choice Affairs especially in aquaculture.
\end{abstract}

Keywords: Management, Aquaculture, Marine and Fisheries Service

\section{Introduction}

Article 33 paragraph 2 of the 1945 Constitution of the Republic of Indonesia states:

"The earth and water and the natural resources contained therein are controlled by the state and are used for the greatest prosperity of the people."'[1]

In this article, it is required that the wealth contained in the earth and the sea is one of the basic capital possessed by the Indonesian Nation in running and managing various sectors of community life in the context of improving people's welfare. This is reiterated in Article 33 paragraph 3 of the 1945 Constitution of the Republic of Indonesia which states that:

"The national economy is organized based on economic democracy with the principles of togetherness, fair efficiency, sustainability, environmental insight, independence, and by maintaining a balance of progress and national economic unity."[2] 
Indonesia, as an archipelagic country has very wide waters containing variety of resources., Geographically, Indonesia's oceans are located in the equatorial area of fisheries.[3] Fish, crabs, shrimps, shellfish, jellyfish, including fisheries that are easily obtained with basic tools. In terms of prospects, fisheries are one of the fields that have a bright future because they have the potential to accommodate various aspects.

Not only technical, equipment, and tropical climate factors that have consequences for the wealth of species and sources of fishing, but the management of fisheries managed in good way and adequate in line with advances in science and technology also supports it.

In accordance with Law No. 23 of 2014 concerning Regional Government states that each local government is given broad authority in carrying out all government affairs ranging from planning, implementation, supervision, control, and evaluation except the authority in the field of foreign policy, defense and security, justice, monetary, fiscal, religious, and other authorities determined by government regulations. [4]

The consequence of broad autonomy authority, every local government has an obligation to improve services and welfare of the community in a democratic, fair, equitable, and sustainable manner. This obligation can be fulfilled if the regional government is able to manage the potential of the region, namely the potential of natural resources, human resources, and potential financial resources optimally. Regional governments in carrying out their governance are required to be able to carry out the development process that can encourage economic growth in order to create the welfare of the wider community. In order to achieve this, the regions are given the right and authority to explore their own regional revenue sources to be able to finance governance and development in the regions. As stated in Law No. 23 of 2014 in Chapter VIII concerning regional finance, it is known that one of the sources of the regional revenue and expenditure budget (APBD) is regional original income (PAD), where in the PAD there are regional taxes and levies area.

Contributions to the Local Revenue of the marine and fisheries sector must be able to be utilized optimally. If it misses, it will result in a large number of terrestrial aquaculture in rural areas that will not get the attention and assistance of the Regional Government of Banyuwangi Regency. The fish feed aid project from the central government will also not be able to be used by fish farmers because of high production costs. [5]

The existence of fisheries resources is a great deal both in terms of quantity and diverse types. They both can be managed and utilized for the welfare of the community. Management of fisheries resources must be done in a good way based on fairness and equity in their use by prioritizing the expansion of employment opportunities and improving the standard of living for fishermen, fish cultivators, and the preservation of fish resources and the environment.

Fisheries are all activities related to the management and utilization of fish resources and the environment from pre-production, production, processing, and marketing. They are carried out in a fisheries business system. The management of fisheries is very diverse, ranging from fishing and cultivating fish, including various activities such as storing, cooling, or preserving that aim to bring in income and profits for fishermen. One of the expected fisheries business is profit.[6]

Law No. 45 of 2009, a Second Amendment of Law No. 31 of 2004 concerning Fisheries, especially in a article 3 states that fisheries management is carried out with the following objectives: a). Increase the standard of living of small fishermen and small-fish farmers, b). Increase foreign exchange earnings, c). Encourage expansion and employment opportunities, d). Increase the availability and consumption of fish protein sources, e). Optimizing the management of fish resources, f). Increase productivity, quality, added value and competitiveness, g). Increase the availability of raw materials for the fish management 
industry, h). Achieve optimal use of fish resources, fish cultivation land, and fish resource environment, i). Guarantee the sustainability of fish resources, fish cultivation land, and spatial planning.[7]

Aware of the vastness of the territorial waters, the Indonesian government took the initiative to give part of the management of the territorial waters to the regional government, both the provincial government and the district or city government in carrying out the broadest possible autonomy, except for functions determined as the affairs of the central government, in Article 18A Paragraph (2) states that, "financial relations, public services, utilization of natural resources and other resources between the central government and regional governments are regulated and carried out fairly and in accordance with the law." Therefore in Article 18 of Law No. 23 of 2014 concerning Government Regions emphasize this authority, where in Paragraph (1) states that, "areas that have sea territories are given authority to manage resources in the sea area."

Meanwhile, in article 14 paragraph (1), (2), and Explanation of paragraph (2) of Law No. 23 of 2014 concerning Regional Government, which regulates mandatory and decentralized functions to become the authority of Regency/City Regional Government, does not mention the existence of Management of affairs/Fishing Port. In selected governmental affairs in accordance with Article 12 paragraph (3) of Law No. 23 of 2014 Includes Government Authority in Managing the Sea. In addition, there are differences in the nature of granting authority in fisheries affairs. If in Law No. 32 of 2004 concerning Regional Government that is decentralized, then in Law No. 45 of 2009 concerning Fisheries is Co-Administration.

As in the attachment of Law No. 23 of 2014 concerning the division of marine/regency/municipal affairs, the authority is only given in capture fisheries, as well as in the case of aquaculture. However, Article 18 of Law No. 23 of 2014 concerning Regional Governments gives authority to the regions in marine management, as well as in Law No. 45 of 2009 concerning Fisheries grants authority to the government and regional governments in accordance with their authority to conduct marine management for the greatest prosperity of the people through the use and authorization of marine resources using the principles of the blue economy. According to the attachment to Law No. 23 of 2014, there are also compulsory and optional functions. The choice of affairs referred to in this article is a government affair that actually exists and has the potential to improve the welfare of the community in accordance with the conditions, uniqueness, and superior potential of the region concerned, one of which concerns marine and fisheries.[6]

In activities related to fisheries in the city of Semarang, they are classified into the agricultural sector. Based on Semarang City BPS data for 2018, the fisheries subsector contributed $5.12 \%$ of the $35.92 \%$ contribution of the agricultural sector to the Gross Regional Domestic Product (GRDP) of Semarang City. With this contribution, the fisheries subsector became the second largest contributor after the food crops subsector for the agricultural sector. Thus, this sub-sector has a significant role for regional income in the city of Semarang.

This sub-category includes all activities of catching, hatching, and cultivating all types of fish and other aquatic biota, all in fresh water, brackish water, and at sea. Commodities produced by fisheries activities include all types of fish, crustaceans, mollusks, seaweed, and other aquatic biota obtained from capture (in the sea and public waters) and aquaculture (sea, pond, cage, floating net, pond, and rice field). Also included in fisheries activities are services that support fisheries activities on the basis of fees or contracts.

Data on fishery commodity production was obtained from the Directorate General of Capture Fisheries and the Directorate General of Aquaculture of the Ministry of Maritime Affairs and Fisheries. Price data in the form of producer prices were obtained from the BPS 
Rural Price Statistics SUBDIT. The price indicator data in the form of the Producer Price Index are obtained from the BPS Statistics Producer SUBDIT and the Index paid by farmers for fisheries group production costs from the BPS Rural Statistics SUBDIT. While the data structure of the cost of fishery activities is obtained from the results of the Agricultural Census and Fisheries Company Survey conducted by BPS Fisheries Statistics Subdit.[8]

If the maritime and fisheries sector of Semarang City is developed intensively through appropriate steps, then this sector will produce a large production value and can be utilized for the economic progress of the people in Semarang City, especially fish farmers and fishermen. A large production value can be used to provide maximum contribution to the Regional Original Revenue.

Based on the background description above, it is important to research the efforts of the Semarang City Maritime and Fisheries Office to improve the management of aquaculture. This is what motivates the author to write and research a legal writing (thesis) with the title "Improvement of Fisheries Management by Marine and Fisheries of Semarang City."

Based on the background that has been explained before, there are several issues that will be discussed in this paper as follows:

1. How is Semarang City's Office of Maritime Affairs and Fisheries to improve the management of aquaculture?

2. What is the solution to the obstacles experienced by the Semarang City Maritime and Fisheries Office?

This normative juridical approach will start from the approach to the Laws and Regulations that implement the improvement of aquaculture management by the Semarang City Maritime and Fisheries Service. The juridical normative approach method is used to obtain data relating to the improvement of aquaculture management by the Semarang City Maritime and Fisheries Office. This research using the normative juridical approach method provides a real and systematic picture.

According to Ronny Hanitijo Soemitro, an empirical juridical approach is a literature approach that is based on regulations, books or legal literature and materials that have relationship problems and discussions in writing this thesis and taking data directly on the object of research related to the increase in research objects management of aquaculture by the Semarang City Maritime and Fisheries Office.[9]

The research specification used in this paper is analytical descriptive, which is analyzing the current problems and describing all the symptoms and facts that exist related to criminal law policies in diverse for children who repeat the crime.

In researching legal issues with a normative juridical approach, this study makes observations by studying and explaining secondary data, which is called the literature study method.

Data analysis in this study was carried out qualitatively from the data obtained, it then compiled systematically and analyzed qualitatively to achieve clarity on the problem discussed. This research was conducted by collecting data, compiling, analyzing, interpreting and describing it. After analyzing the data, conclusions can be obtained using the inductive inference method, which is a way of thinking in drawing conclusions in general based on specific facts.[10] The reason for using qualitative analysis because the data was collected in the form of question. The data collected contains general information and the relationship between variables cannot be measured by numbers. 


\section{Results and Discussion}

\subsection{Semarang City Maritime Affairs and Fisheries Agency's Efforts to Improve Aquaculture Fisheries Management}

As a consequence of broad autonomy authority, every local government has an obligation to improve services and welfare of the community in a democratic, fair, equitable, and sustainable manner. This obligation can be fulfilled if the regional government is able to manage the potential of the region, namely the potential of natural resources, human resources, and potential financial resources optimally. Regional governments in carrying out their governance are required to carry out the development process that can encourage economic growth in order to create the welfare of the wider community. In order to achieve this, the regions are given the right and authority to explore their own regional revenue sources to be able to finance governance and development in the regions. As stated in Law No. 23 of 2014 in Chapter XI concerning regional finance, it is known that one of the sources of regional revenue and expenditure budget (APBD) is regional original income (PAD), where in the PAD there are regional taxes and levies area.

In order to contribute to the Regional Revenue of the marine and fisheries sector, it must be able to be utilized optimally, and when it misses, it will result in a lot of terrestrial aquaculture in rural areas that will not get the attention and assistance of the Semarang City Regional Government. The fish feed aid project from the central government will also not be able to be used by fish farmers because of high production costs.

\subsection{The Policy Direction of Semarang City Maritime and Fisheries Service Program as an Effort to Improve Aquaculture Fisheries Management}

The Policy Direction Program of the City of Maritime Affairs and Fisheries in the City of Semarang as an Effort to Improve Cultivation Fisheries Management is directed at Increasing the Utilization of Aquaculture Fisheries Resources Optimally, while maintaining environmental sustainability through improving the quality of human resources, optimally managing the potential of aquaculture fisheries through the program.

In 2018 the programs implemented in the Maritime Affairs and Fisheries Affairs Affairs are as follows:[11]

1. Aquaculture development program. This program is directed at the development of Superior Fish Seedlings, Improvement of Infrastructure Facilities, and Aquaculture Production.

2. Fisheries extension system development program. This program is aimed at increasing fish consumption.

3. Program for optimizing the management and marketing of fisheries production. This program is aimed at increasing the processing of fisheries human resources to improve the quality and quantity of processed fish products.

Activities that support the achievement of service performance in the Capture Fisheries Development Program include activities for improving and developing fish culture technology; environmental management and fish disease control activities; fish breeding and development activities; revitalization of freshwater aquaculture fisheries; revitalization of brackish aquaculture fisheries and infrastructure and development activities. 
This was also supported by several programs included in the Policy Direction of the Semarang City Maritime and Fisheries Service Program as an Effort to Improve Aquaculture Fisheries Management including:

1. Aquaculture development program. This program is directed at the development of Superior Fish Seedlings, Improvement of Infrastructure Facilities, and Aquaculture Production. This program is implemented through the development of smallholder fisheries and the development of superior fish seeds with the aim of enhancing the knowledge and skills of resilient fish farmers and environmentally friendly aquaculture.

2. Fisheries extension system development program. This program is aimed at increasing fish consumption. This program is carried out through the activities of fostering, counseling and promotion of fishery products as well as strengthening and developing fisheries product marketing with the aim of popularizing fishery products.

3. Program for optimizing the management and marketing of fisheries production. This program is aimed at increasing the processing of fisheries human resources to improve the quality and quantity of processed fish products.

\subsection{Barriers experienced by the City of Semarang Maritime and Fisheries Office}

Semarang City Maritime Affairs and Fisheries Office in carrying out government affairs in the field of maritime affairs and fisheries can not be separated from the problems that prevent in achieving the vision and mission. These obstacles are:

\subsubsection{Utilization of Fish Farming Land}

Utilization of cultivated land is not yet optimal and there is still low ability of fish cultivators in applying Good Aquaculture Practices (CBIB). A Good Way of Fish Cultivation is the application of how to maintain and or raise fish and harvest the results in a controlled environment so as to provide food security from cultivation by paying attention to sanitation, fish medicine feed and chemicals and biological materials. Improving the quality of aquaculture products is more directed at providing food safety guarantees starting from raw materials to the end products of aquaculture that are free from contaminants as in accordance with global market requirements. How to obtain CBIB certification is by making a submission effort by aquaculture entrepreneurs, both individuals, groups of farmers (POKDAKAN) and business entities with the following conditions:

1. Application for CBIB Certification is addressed to the Head of the Provincial Marine and Fisheries Service, completed with administrative documents and copied to the Head of the Regency/City Maritime and Fisheries Service. Administrative documents include:

a) Photocopy of Fishery Business Permit (SIUP) for a legal entity business unit or a sign/record of fish cultivation business for an individual business unit or the inauguration of a fish cultivator group;

b) General data on fish cultivation units;

c) List of facilities for fish cultivation units;

d) List of records/records of fish farming unit activities;

e) The number and education of fish cultivation workforce (organizational structure and job descriptions, for groups or companies);

f) Drawings of building layouts, maps and conditions surrounding the fish cultivation unit. 
2. Requirements for the applicant (fish breeding unit) who submit CBIB Certification include:

a) Business scale can be in the form of individuals, fish cultivator groups (POKDAKAN) or companies that produce consumption fish species and are marketed locally and for export;

b) Has conducted a cultivation business of at least 1 planting season;

c) Aquaculture business activities at the stage of breeding and or enlargement of fish.

3. Applications can be submitted directly or by post, fax and or electronic mail.

\subsubsection{The absence of providing aid equipment to the cultivating community}

The training materials given by the government could not be used for entrepreneurs because there was no assistance in equipment; while, the community did not have capital for entrepreneurship. In another policy, the Fisheries Service is not permitted to give grants to fish farmers. However, it can only provide counseling, assistance, and propose procurement of goods to the provincial and central government through the KKP.

\subsubsection{Land Use}

Lack of use of idle land for inland fisheries, especially land that has a source of water for fisheries activities so that the production of freshwater aquaculture is not optimal.

\subsubsection{High Abrasion}

For brackish water aquaculture, high abrasion and high tides cause coastal ponds bordering the sea to be damaged and often fail to harvest.

\subsubsection{Superficiality}

The construction of the maritime village area has an impact on fishermen's income because the development of the area has caused river siltation, making fishing boats difficult to enter and exit TPI.

\subsubsection{Lack of Community Interest}

There is still a lack of community interest in consuming fish, especially among children, so that various counseling efforts are needed that attract children.

\subsubsection{The land acquisition}

The procurement of conservation land cannot yet be realized in the previous year due to the incompatibility of land acquisition planning documents with the RTRW documents for the location of the aquaculture land. The land acquisition planning document is written for conservation while the allotment of land in the intended location according to the RTRW is for tourism and settlement.

Strategic issues and general issues that are the main obstacles in realizing sustainable fisheries activities in Indonesia are: 1) fisheries management; 2) law enforcement; and 3) fisheries business actors. The weakness of the fisheries management system is a strategic issue and a major general problem in realizing a sustainable fisheries sector in Indonesia. This has been indicated by uneven levels of utilization of fish resources in the territory of Indonesia.

The condition of law enforcement for the fisheries sector in Indonesia is also relatively weak, both in quantity and quality. The lack of law enforcement in the field of fisheries, 
besides causing state losses, both economically and environmentally, it also has an impact on the enforcement of the country's territorial sovereignty. Aquaculture is a spatial regulation problem that is often violated or not adhered to without strict action from the government or law enforcement officers. In fact, not a few spatial rules replaced or adjusted to personal interests or groups of authorities.

\subsection{Solution to the Obstacles experienced by the Semarang City Maritime and Fisheries Office}

In general, the problems faced by fish farmers in Semarang City include capital, cultivation technology (seed quality, water quality, land and canals), feed prices, market and marketing, and diversification of processed products. So that the solutions of the problems found can be classified based on their respective problems, namely:

\subsubsection{Capital}

Capital for fish farmers in the city of Semarang is a major problem that makes it difficult to develop their business into a large scale business. Provision of Small and Medium Enterprises Loans (KUKM) needs to be intensified with requirements that do not burden farmers. This can be done through recommendations from the local industry and fisheries service and helping groups of fishery business actors to take care of the legal establishment of the group so that they are eligible to receive assistance from the government.

\subsubsection{Human Resources}

Identification of idle lands close to water sources is carried out to be developed as freshwater fish farming, and to provide socialization and training on fish farming to the community by forming groups of fish farmers. In addition, conducting training for the Group of fish cultivators by following classification is needed:

a. Beginner Group. In the initial stage of development, the Department of Fisheries provides basic training and counseling such as the manufacture of independent feeds, management of clean water sources, and neat and coordinated salinity. So it does not cause a lot of waste and make the quality of fish farming results become better.

b. Associate Group. In the middle group coaching stage, the Semarang City Fisheries Department began to provide a specific understanding of the types of fish culture such as Biofloc and Tilapia Salin. This type of cultivation is relatively new and requires Human Resources who are experienced in aquaculture.

c. Main Group. The Fisheries Service only provides assistance in the post-production stage to the main Group, usually at the stage the main group has cooperated with other agencies such as the trade service for marketing, the industry service for the packaging and industrial cultivation of fish.

\subsubsection{Implementation of Permanent Quality Management}

The Quality Management assistance method continues to promote interactive discussions in business locations. So the problems that occur can be immediately found a solution together. Preliminary mentoring results show that the farming systems used are mostly still using semi-intensive fish farming systems. This is a concern, and at the same time an opportunity for the team and partners so that fish farming activities can implement an intensive fish culture system, while maintaining the quality of aquaculture media according to fish seed requirements, so that fish seed production can continue and be able to meet 
production targets. The next training is how to make independent food and fish feed management. Specifically, partners are given an understanding and skills on how to choose feed raw materials that are suitable to the nutritional needs of fish, especially feed raw materials that have been available at partner locations such as shrimp shell waste, and trash fish that can be used as raw materials for making fish feed, namely silage.

The next step is the management of water quality management. The participation of partners in this activity is very good, the activities include controlling the tub or pool of water filters, installations, tools used in the process of taking sea water, as well as measuring water quality using a water temperature thermometer, oximeter to measure the content of dissolved oxygen in water, and $\mathrm{pH}$ test or litmus to measure the $\mathrm{pH}$ of water. Through this activity, water quality measurements should have been carried out continuously so that water quality management efforts can continue to be monitored, and appropriate for fish hatchery activities. Based on the analysis of the availability of raw materials for making fish feed which is quite high in partner regions such as shrimp head waste, trash fish, bread waste, and tofu waste. So the initial step taken is the transfer of information related to fish feed nutrition, preparation of feed formulations, how to make independent fish feed, and the use and maintenance of fish feed machines. So that partners are able to produce fish feed independently to meet feed needs during seed production, and are able to reduce production costs.

\subsubsection{Cultivation Technology}

The cultivation technology applied generally still applies traditional technology and not many have implemented intensive patterns. It is necessary to improve the cultivation techniques by increasing the function of counseling, accompaniment, as well as a Dempon or demonstration plot. Seed quality is a problem because of the slow growth of milk fish. This is allegedly due to the poor quality of the seeds used, so that the support of superior seeds produced by research institutions and the People's Breeding Unit (UPR) that have received certificates is very much needed, through procurement, as well as good management of the parent to produce high quantities of continuous and high quality seeds. The condition of water quality used in aquaculture has declined significantly with the amount of pollution coming from industry, ship washing waste in the middle of the sea, or oil/diesel spills.

In addition, land and water management is generally not carried out optimally due to the malfunctioning of waterways due to siltation of channels. So that it is necessary to stipulate local regulations and strict sanctions for industries that dispose of their waste and have the potential to pollute the surrounding waters, normalization of pond channels with support from the local government and participation of POKDAKAN in the maintenance of the channel independently, as well as the use of modified boat complainants.

The steps to overcome these fish culture problems are to improve the technical development of fisheries and fishing, and to improve the facilities and infrastructure of aquaculture and capture fisheries. This is done by improving land management for fish farming and improving facilities and infrastructure at the Auction Fish Ponds of the pond to maintain the canals.

\subsubsection{Price of Feed}

Fish farmers often complain that the high price of feed they use, so that in economic calculations the difference between operational costs and the selling price of fish is no longer sufficient, resulting in very little profit received. The development of household-scale feed industry by utilizing local raw materials is needed to overcome the high price of feed. 


\subsubsection{Market and Marketing}

Limited market absorption results in saturated prices, when the production is abundant, there is often a decline in prices and on the other hand, production costs cannot be reduced. It is necessary to stabilize the price of milkfish in the form of warehouses or cold storage that can accommodate milkfish when abundant production. The provision of cold storage that is professionally managed by both private and government. They will be very beneficial, especially when milkfish production is abundant during the main harvest season.

Provision of local markets with adequate facilities both space, containers and other supporting facilities such as: the availability of ice and the smooth transportation with the support of the local government. In addition, for the distribution of processed products it is necessary to provide a special market as a place to sell processed products as well as a place of promotion.

To increase per-capita fish consumption, fishery product processing innovations are carried out by making various types of processed fish-based menus and socializing and providing training to the community.

\subsubsection{Diversification of Processed Products}

The limited knowledge of farmers about fish processing is also a problem that always happens. Therefore, it can be found out that there is a need for training from postharvest institutions in coordination with the local industry and fisheries service, in the field of milkfish processing for both farmers and processors. In addition, so that milkfish cultivation products can be absorbed optimally, it can be done by increasing the number of milkfish processing entrepreneurs and by increasing the role of cooperatives in collaboration with banks, as well as through the promotion of nutritionists who coordinate with local related agencies in order to improve fish eating patterns milkfish in Semarang City.

From these problems, some recommendations that can be used in order to increase production and productivity of fish farming in the city of Semarang include several aspects including: provision of Small and Medium Enterprises Credit (KUKM), refinement of cultivation techniques, market supply and improvement, diversification of milkfish processed products, and providing other supporting facilities.

\section{Conclusion}

Based on the problems discussed in the previous chapter, the following conclusions can be drawn:

1. The Semarang City Maritime and Fisheries Service Office attempts to improve the management of aquaculture in an Optimal Increase in the Utilization of Aquaculture Resources. they also maintain environmental sustainability through enhancing the quality of human resources, optimally managing the potential of aquaculture Fisheries Development, and the programs implemented in the Affairs The choice of Maritime Affairs and Fisheries especially in aquaculture is as follows:

a. Aquaculture development program. This program is directed at the development of Superior Fish Seedlings, Improvement of Infrastructure Facilities, and Aquaculture Production.

b. Fisheries extension system development program. This program is aimed at increasing fish consumption. 
c. Program for optimizing the management and marketing of fisheries production. This program is aimed at increasing the processing of fisheries human resources to improve the quality and quantity of processed fish products.

2. The solution to the obstacles experienced by the Semarang City Maritime and Fisheries Service can be seen from several aspects which include the potential of cultivated land, cultivation techniques, production/productivity, marketing, problems and solutions needed, and in order to increase production and marketing in Semarang City, Central Java. As a whole requires a touch of applicable cultivation technology accompanied by comprehensive cooperation between the central government, local governments, and fish farming communities in the city of Semarang so that it can support improved management in the field of aquaculture.

\section{Suggestion}

1. Developing policies regarding management plans more clearly for fisheries resources is the most important thing to do in the institutional aspect. This is supported by many laws regarding the management of fisheries resources that are not yet clear. In addition, unclear fisheries resource management policies also have an impact on the integration of various parties, both those involved directly or indirectly in fisheries resources. Because the integration is not very good, the practice of coordination between elements that occur in the field is not as good as expected. On the one hand, there are those who want the sustainability of fisheries resources to be maintained while on the other hand there are also those who depend on fishery resources and are often aware of or have not caused a crisis of fisheries resources due to excessive extraction. Fisheries management has not been able to run effectively due to the absence of adequate local regulations and overlapping policies, so the management plan has not been optimal. Therefore, it is necessary to develop a clearer and more appropriate management plan and regulation for fisheries resources.

2. The application of conventional management models has not been able to run optimally. Therefore, a solution is needed so that the management of fisheries resources in Indonesia can run optimally. Ecosystem based fisheries management as a new paradigm is thought to be a solution for fisheries resource management. Although it might be difficult and it takes a long time to see the success of this model if it is applied in Indonesia.,. To apply this model, it can be adjusted to the conditions and all characteristics associated with fisheries resources. Ecosystem based fisheries management can be applied in Central Java Province, especially in Semarang City. The proposed management plan for fisheries resources in the discussion chapter can be implemented by referring to the policy of Law No. 23 of 2014 concerning Regional Government. In terms of developing strategies for managing ecosystembased fisheries resources carried out by considering several aspects, namely the aspects of theology, economic aspects, social aspects, institutional aspects, and environmental aspects. Whereas the priority in formulating a strategy for management of fisheries resources is carried out by restoring and maintaining the condition of the living places (habitat) of fish; make fisheries management policies 
that are adjusted to the cultural values of the community; and create a database of information on the types of fish being cultivated. 


\section{References}

[1] Article 33 paragraph 2 Constitution of the Republic of Indonesia 1945.

[2] Article 33 paragraph 3 Constitution of the Republic of Indonesia 1945. .

[3] D. M. R. Siombo, Hukum Perikanan Nasional dan Internasional. Jakarta: Gramedia Pustaka Utama, 2013.

[4] Law No. 23 of 2014 concerning Regional Government. .

[5] A. D. Agustine, "Pengembangan Sektor Kelautan dan Perikanan Untuk Meningkatkan Pendapatan Asli Daerah (Studi di Dinas Kelautan dan Perikanan Kabupaten Banyuwangi)," J. Adm. Publik, vol. 2, no. 2, pp. 276-280, 2014.

[6] A. Putra, O. P. K., Soemarmi, A., and Diamantina, "Pelaksanaan Tugas dan Wewenang Dinas Kelautan dan Perikanan dalam Pengolahan Hasil Perikanan di Kabupaten Pati," Diponegoro Law J., vol. 6, no. 1, pp. 1-15, 2017.

[7] Law No. 45 of 2009 Concerning Fisheries. .

[8] Badan Pusat Statistik Kota Semarang, Produk Domestik Regional Bruto Kota Semarang Menurut Lapangan Usaha. Semarang: CV. Citra Ayunda, 2018.

[9] R. H. Soemitro, Metodologi Penelitian Hukum dan Jurimetri. Jakarta: Ghalia Indonesia, 2001.

[10] P. M. Marzuki, Metode Penelitian Hukum. Jakarta: Kencana Prenada Media, 2005.

[11] Dinas Kelautan dan Perikanan Provinsi Jawa Tengah, Rencana Strategis Dinas Kelautan dan Perikanan Provinsi Jawa Tengah 2013-2018. Semarang, 2013. 